\title{
What is the Better Social Media for Mathematics Learning? A Case Study at A Rural School in Yogyakarta, Indonesia
}

\author{
1Dwi Sulisworo, 2Kasem Permprayoon \\ 1Universitas Ahmad Dahlan, Jl. Prof. Dr. Supomo, Janturan, Yogyakarta, Indonesia \\ 2Thaksin University, เลข ที่ 140 ม .4, Khao Rup Chang, Mueang Songkhla District, Thailand \\ e-mail: dwi.sulisworo@uad.ac.id
}

\begin{abstract}
Abstrak
Penetrasi media sosial di masyarakat sudah sangat tinggi. Saat ini, hampir semua siswa di sekolah menggunakan ponsel cerdas untuk aktivitas keseharian mereka. Penelitian ini merupakan penelitian eksploratif kuantitatif deskriptif untuk mengetahui bagaimana respon siswa ketika belajar menggunakan media sosial sebagai sistem pembelajaran mobile. Data diambil dari empat sekolah berbeda di daerah pedesaan Yogyakarta, Indonesia. Pembelajaran matematika dilaksanakan dengan menggunakan media sosial yang berbeda (WeChat, Line@, Socrates, dan Edmodo) pada siswa kelas 7 di masing-masing sekolah. Pengumpulan data menggunakan kuesioner USE yang mengukur apakah model pembelajaran yang diimplementasikan dengan menggunakan media sosial dapat diterima dengan baik oleh siswa dan pembelajaran sesuai dengan harapan. Kuesioner USE memiliki 4 faktor terukur yaitu kegunaan, kemudahan penggunaan, kemudahan belajar, dan kepuasan. Dari data tersebut, terlihat bahwa semua faktor yang diukur memperoleh skor yang tinggi. Skor tertinggi adalah kepuasan $(3,15)$ kemudian kegunaan $(3,11)$, mudah dipelajari $(3,00)$, dan mudah digunakan $(2,94)$. Rata-rata, media sosial mendapat respon siswa yang tertinggi sebagai sistem pembelajaran yaitu Socrative (3.18), lalu Edmodo (3,15), Line@ $(3,00)$ dan WeChat $(2,89)$. Analisis lebih lanjut Anova menunjukkan bahwa Socrative dan Edmodo merupakan aplikasi yang cenderung dipersepsi paling baik oleh siswa. Temuan ini bermakna bahwa kedua aplikasi tersebut perlu dimanfaatkan dalam pembelajaran dengan berbagai strategi pembelajaran.
\end{abstract}

Kata Kunci: social media, mobile learning, STEM education, mobile technology, learning innovation

\begin{abstract}
The penetration of social media in the community has been very high. Nowadays, almost all students at the school are using smartphones for their daily activities. This study is a descriptive quantitative exploratory research to find out how the students' response when learning using social media is implemented as a mobile learning system. Data were taken from four different schools in the rural area of Yogyakarta, Indonesia. Mathematics learning using a different social media (WeChat, Line@, Socrative, and Edmodo) was applied to student of grade 7 of each school. Data collection used USE questionnaire which measured whether the implemented learning model using social media could be well received by students and appropriate learning expectations. USE questionnaire has 4 measured factors i.e. usefulness, ease to use, ease of learning, and satisfaction. From the data, it shows that all factors were high. The highest one was satisfaction (3.15) then, usefulness (3.11), ease to learn (3.00), and ease to use (2.94) respectively. On average, the social media got the highest student's response as a learning system was Socrative (3.18), then Edmodo (3.15), Line@ (3.00) and WeChat (2.89). Further analysis using statistical technique showed that students have good perception to Socrative and Edmodo. This finding implies that the social media especially Socrative and Edmodo are valuable to be used in the leaning using flexible learning strategy.
\end{abstract}

Keywords: social media, mobile learning, STEM education, mobile technology, learning innovation

How to Cite: Sulisworo, D., \& Permprayoon, K. (2018). What is the better social media for Mathematics learning? A case study at rural school in Yogyakarta, Indonesia. International Journal on Emerging Mathematics Education, 2(1), 39-48. http://dx.doi.org/10.12928/ijeme.v2i1.7071 


\section{INTRODUCTION}

The concept of the 21st century learning has been widely adapted by a lot of countries in the world to do the learning revolution to create the better generation. This concept supports to provide the learning environment where students master the learning material while producing, synthesizing, and evaluating the information from various sources with awareness on respect towards various cultures (Farisi, 2016; Gulden et al., 2012). In this learning environment, students do not only master the three Rs (Reading, Writing and Arithmetic), but also nowadays using various software and virtual devices broadens their learning scope to be unlimited in terms of space, time and with whom they study (Farisi, 2016; Gulden et al., 2012; Zyad, 2016).

Optimism related to learning in digital era highly feels at schools in Indonesia as well as at other countries (Mahdi et al., 2014; Ülen \& Gerlič, 2012; Uyanga, 2005). However, at schools in the rural area in Indonesia, there are various problems which need to consider in order to giving the same learning access to students (Sulisworo et al., 2017). This problem has also been studied by other researcher (Kola, 2013; Mahdi, et al., 2015; Okpurukhre \& Esiekpe, 2013; Owate et al., 2014). The penetration level of ICT in Indonesia which evenly spread in every area becomes an opportunity for the implementation of the 21st century learning. With the existence of technology development nowadays, the question is whether technology can support the achievement as a useful human being in the society (Sulisworo \& Toifur, 2016; Sulisworo et al., 2017). The use of technologies will continue to increase globally and it is a challenge for educators to ensure that technology will become a part of their use (Alzahrani \& Laxman, 2016; Kabir \& Kadage, 2017; Zyad, 2016). The unreadiness of the society particularly in education to utilize the technology may become a nightmare for students in learning to keep struggling as a society member (Sadaf et al., 2016; Sulisworo et al., 2016).

The rapid development of technology especially mobile technology has influenced the learning success criteria. The changing in learning environments and interactive learning between technology components will affect the strategies and approaches to learning in order to facilitate student success (Alzahrani \& Laxman, 2016). Several researches show that kids now grow in the environments which utilize the technology especially mobile technology with its various functions (Kumar \& Owston, 2016; Sulisworo \& Toifur, 2016). They feel it in their daily life and it integrates to them. Meanwhile, there is a tendency that they do not get what is expected in learning at school. They face a learning situation using old approaches. This inappropriateness becomes one of failure factors in education now (Kabir \& Kadage, 2017). An effective interaction among teachers, students, learning sources, learning media which utilize mobile technology becomes a success key in the learning competence achievement (Bozanta, 2017; Furberg, 2016; Kashorda, et al., 2007; Sadaf et al., 2016; Yadegaridehkordi et al., 2015).

Information technology has facilitated a variety of new learning approaches that allow students to develop naturally driven by their own interests (Fidaldo \& Thormann, 2017; Gómez-rey et al., 2017; Yadegaridehkordi et al., 2015). They can find a wide range of knowledge through independent thinking and real-world experience. Their active role on navigating in cyberspace to make a decision about how to look for, where to look, what content to select related to their business and increase their understanding of the particular competence (Gulden et al., 2012; Sulisworo et al., 2016; Zyad, 2016). 
Technology integration in learning can enrich learning experiences. Mobile learning gives opportunity for students to involve in their learning experience which now can't be got through static technology devices such as a desktop computer (Alzahrani \& Laxman, 2016; Kumari \& Chamundeswari, 2013; Zawacki-richter et al., 2017). At the moment, the changing in teaching and learning philosophy is driving from a teacher-centered approach to a student-centered approach. Two paradigm shifts in computation and education which is student-centered. In another side, mobile technology gives more possibilities to improve the teaching quality in many aspects. Student's ability in actively building the knowledge, rather than more passively responding a tutorial action is very important in the new learning approach (Barak et al., 2011; Sadaf et al., 2016). Constructivism learning approach drives to think explicit learning, reasoning, problem solving and effective skill planning, learning to learn from a mistake, and developing reflective meta-cognitive skill (Furberg, 2016; Ludvigsen et al., 2016).

General understanding of constructivism is by actively trying to make something concrete (physic or computation) to solve a problem. Articulation and reflection on their thought is whether it works or a necessary revision that is common in constructivist approach (Ludvigsen et al., 2016). Teacher and students have to involve in an active dialog. Several design-based studies have scrutinized how various forms of digital support tools can support students' work in school science (Furberg, 2016). An effective method for knowledge setting must be simplifying, producing a new proposition, and increasing information manipulation to scaffold teachers and students through automatic analysis and feedback (Ludvigsen et al., 2016). There are three basic principles in the approach which must focus on experience and context which make students to wish and to be able to study (readiness), the instruction must be well structured so it can be easily understood by students, and learning must be planned to facilitate extrapolation and to fill the understanding gap up.

Yogyakarta is a province considered as the best learning center in Indonesia since a long time ago. Nationally, internet traffic in Yogyakarta is the highest in Indonesia. It shows that society in Yogyakarta have good IT awareness and literacy. However, it can't be neglected that the welfare between city and village has not spread evenly including the quality of education. Yet, a smartphone can commonly be found at schools in the rural area. In contrast, it's still lack of a policy that supports learning by integrating this technology in the school teaching and learning. In the future, it can be an obstacle for learning change that suits to the characteristics of the 21st century learning.

Considering various problems in the rural area in the digital era, it needs to explain how the students' comfort when involving in learning that utilizes ICT is. The index digital data shows that utilization of social media highly increases year by year. It indicates the comfort on virtual interaction is high in various circles. Therefore, the utilization of social media as learning interaction media is also predicted high. This research objective is to find out how students' response when they involve in learning using social media. Several types of social media are used for learning, so it can be seen the different effects of the social media in the level of students' acceptance in learning.

\section{RESEARCH METHOD}

The design of this study is a descriptive quantitative exploratory research to find out how the students' response when learning using social media as a mobile learning system is implemented. 
The population is 7 grade student at Bantul Regency, Yogyakarta Province, Indonesia. The sampling technique is purposive sampling which select the student who uses smartphone. Number of sample was 82 students $(28$ students for Socrative, 14 students for Line@, 27 students for WeChat, and 13 students for Edmodo).

All samples are taught mathematics using a different social media. It can be called as fully mobile learning. Teacher and Students interact on learning the mathematics only through the smartphone based application. The learning duration is about 2 hours per day, 3 times per week for 2 weeks.

The data collection of student's response used USE questionnaire which measured whether the implemented learning model using social media could be well received by students and appropriate learning expectations. The Likert scale from 1 to 4 was used at the questionnaire. The questionnaire contained 4 factors i.e Usefulness (8 items), Ease of use (11 items), Ease of learning ( 4 items), and Satisfaction (7 items). This questionnaire was adapted from Lund (2001).

All data are analyzed statistically using SPSS. The result of the student response to certain learning media is compared using one way analysis of covariance or one way- ANOVA at significant level 0.05 .

\section{RESULTS AND DISCUSSION}

Table 1 shows the descriptive result of the student response after certain mobile media were implemented on their learning. From this table, it can be analyzed which one gets higher response than others.

Table 1. Descriptive Statistic

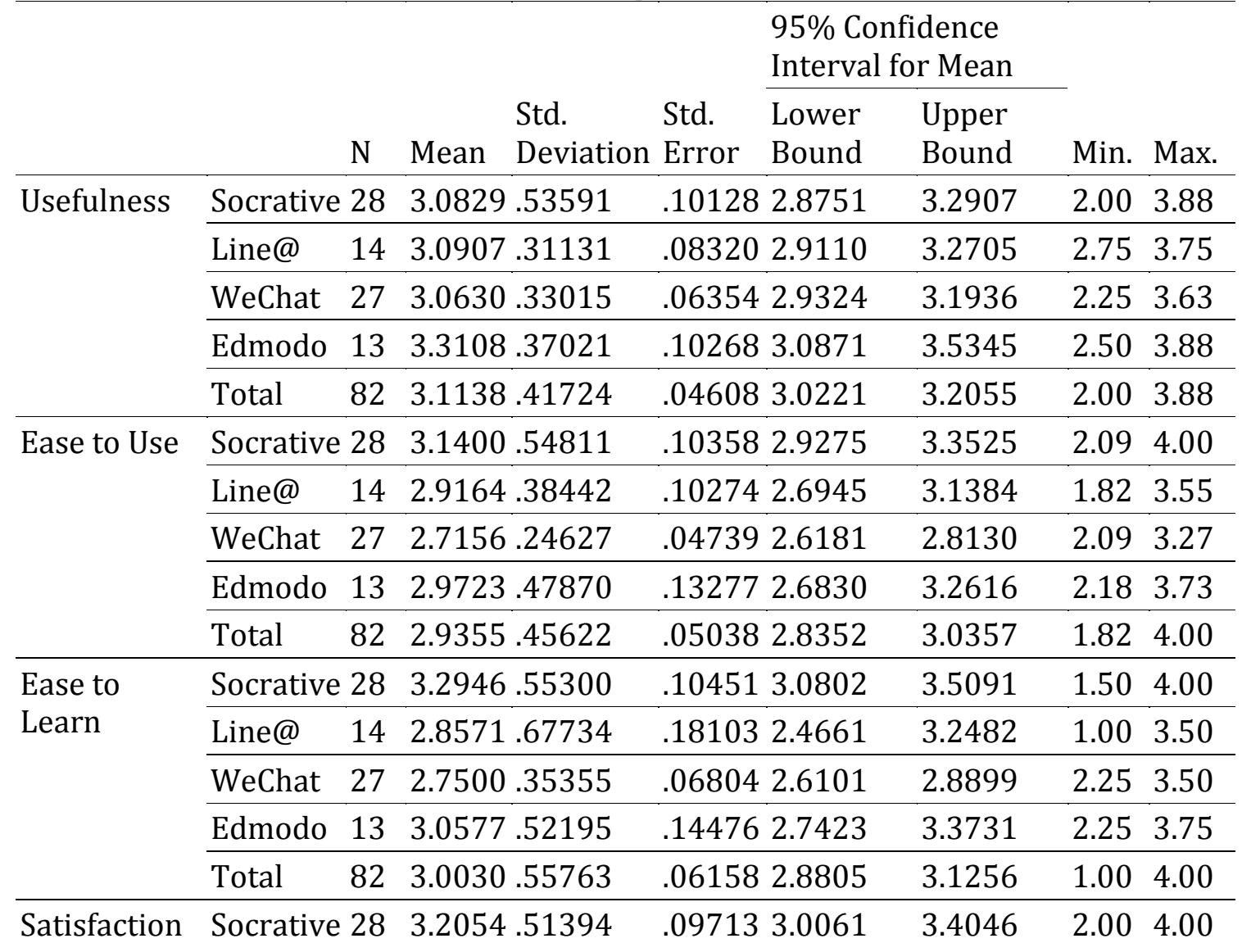

IJEME, Vol. 2, No. 1, March 2018, 39-48. 


\begin{tabular}{|c|c|c|c|c|c|c|c|c|c|}
\hline & & \multirow[b]{2}{*}{$\mathrm{N}$} & \multirow[b]{2}{*}{ Mean } & \multirow[b]{2}{*}{$\begin{array}{l}\text { Std. } \\
\text { Deviation }\end{array}$} & \multirow[b]{2}{*}{$\begin{array}{l}\text { Std. } \\
\text { Error }\end{array}$} & \multicolumn{2}{|c|}{$\begin{array}{l}\text { 95\% Confidence } \\
\text { Interval for Mean }\end{array}$} & \multirow[b]{2}{*}{ Min. } & \multirow[b]{2}{*}{ Max } \\
\hline & & & & & & $\begin{array}{l}\text { Lower } \\
\text { Bound }\end{array}$ & $\begin{array}{l}\text { Upper } \\
\text { Bound }\end{array}$ & & \\
\hline & Line@ & 14 & 3.1529 & .45981 & .12289 & 2.8874 & 3.4183 & 2.00 & 4.00 \\
\hline & WeChat & 27 & 3.0204 & .45575 & .08771 & 2.8401 & 3.2007 & 2.00 & 3.86 \\
\hline & Edmodo & 13 & 3.2692 & .54449 & .15102 & 2.9402 & 3.5983 & 2.00 & 4.00 \\
\hline & Total & 82 & 3.1456 & .49142 & .05427 & 3.0376 & 3.2536 & 2.00 & 4.00 \\
\hline \multirow{5}{*}{$\begin{array}{l}\text { Total score } \\
\text { of USE }\end{array}$} & Socrative & 28 & 3.1801 & .45204 & .08543 & 3.0049 & 3.3554 & 2.30 & 3.89 \\
\hline & Line@ & 14 & 3.0037 & .40396 & .10796 & 2.7705 & 3.2370 & 1.92 & 3.64 \\
\hline & WeChat & 27 & 2.8864 & .25011 & .04813 & 2.7874 & 2.9853 & 2.40 & 3.37 \\
\hline & Edmodo & 13 & 3.1517 & .37432 & .10382 & 2.9255 & 3.3779 & 2.48 & 3.78 \\
\hline & Total & 82 & 3.0488 & .38981 & .04305 & 2.9631 & 3.1344 & 1.92 & 3.89 \\
\hline
\end{tabular}

From the collected data of the student response after involving on learning using the certain social media, the characteristics of the mean can be figured out based on Table 1. The descriptive statistics of the data is shown by Figure 1.

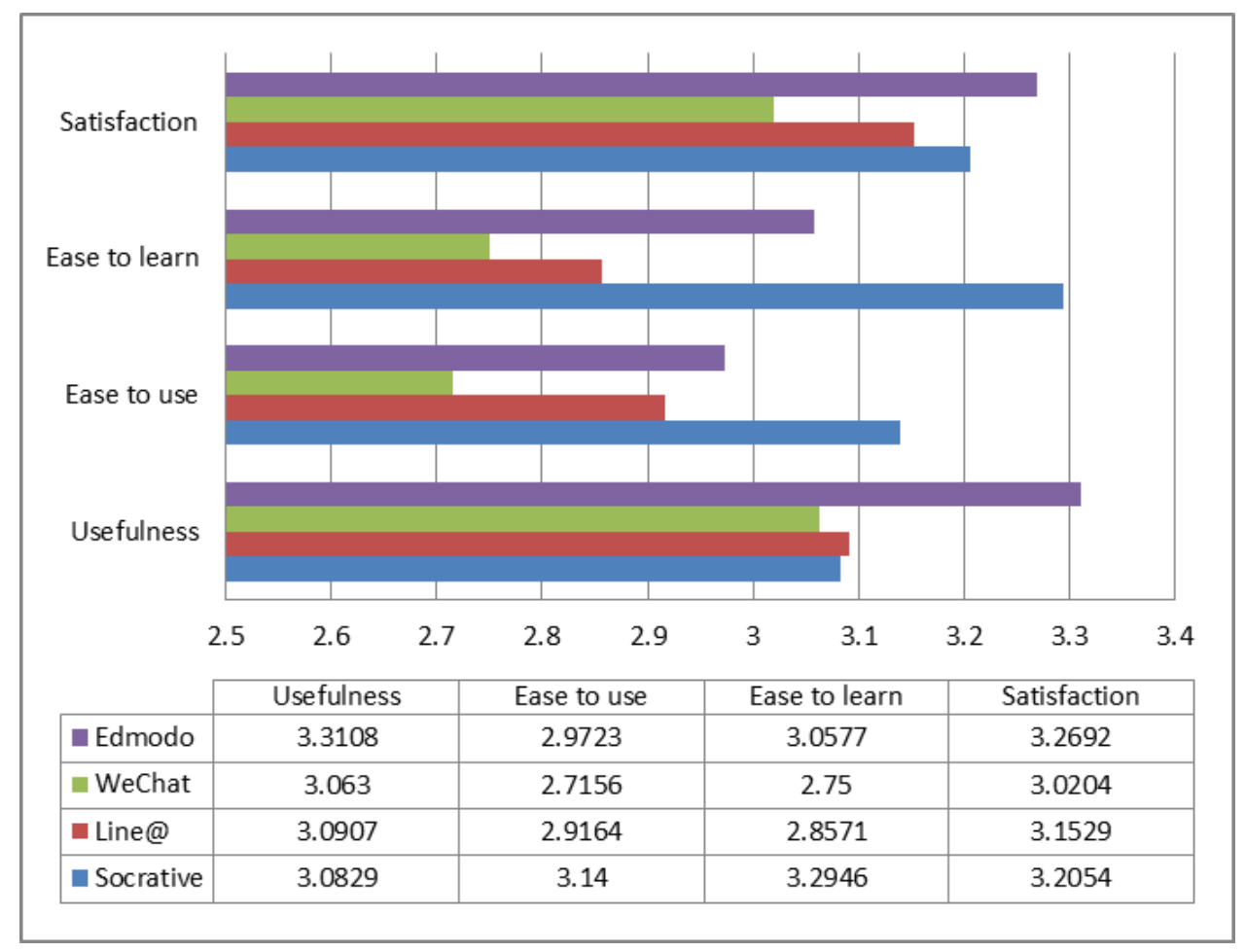

Figure 1. Comparison of the result of the descriptive statistics

Based on the figure 1, the student response is good (higher than 2.5) for all social media used. The means for usefulness and satisfaction factors are higher than 3 for all social media. Yet, for the ease to use only Socrative gets response higher than 3.0, Edmodo and Socrative get response higher than 3.0 for the Ease to learn factor. 
Furthermore, all these differences can be calculated for its significance using the ANOVA statistics. The table 2 shows the result of this statistic calculation.

From the figure 1, it can be seen that all media used are responded quite high (between 2.75 to 3.31). It shows that students now tend to be more comfortable with mobile learning. It is an important phenomenon for schools when adapting the learning environment according to the 21st century learning. It can also be concluded that learning adapting student's daily condition which is close to mobile technology e.g. smart phone and tablet tends to motivate student enthusiasm better. With the higher student learning interest, the better competence can be achieved by students.

In detail, the result of statistical analysis (table 1) shows that there is a significant influence of learning media used in mobile learning activities (see table 1, row of Total score of USE). There is a difference among students who use Edmodo, WeChat, Line@ and Socrative. The response of students using WeChat in learning tends to be lower compared to other media. It may occur because this application is new for students in learning. The result data on Ease to use factor and Ease to learn for WeChat is the lowest of all. This lowest result can be explained that student who used WeChat were not so familiar on it. This situation should be considered on the result comparison analysis. The role of teacher to arrange some activities to scaffold the student on using the learning media is very important (Ludvigsen et al., 2016) so student become familiar to the learning strategy and activity.

Table 2. Analysis of Variance

\begin{tabular}{|c|c|c|c|c|c|c|}
\hline & & Sum of Squares & $\mathrm{df}$ & Mean Square & $\mathrm{F}$ & Sig. \\
\hline \multirow[t]{3}{*}{ Usefulness } & $\begin{array}{l}\text { Between } \\
\text { Groups }\end{array}$ & .608 & 3 & .203 & 1.172 & .326 \\
\hline & Within Groups & 13.493 & 78 & .173 & & \\
\hline & Total & 14.101 & 81 & & & \\
\hline \multirow[t]{3}{*}{ Ease to Use } & $\begin{array}{l}\text { Between } \\
\text { Groups }\end{array}$ & 2.500 & 3 & .833 & 4.526 & .006 \\
\hline & Within Groups & 14.359 & 78 & .184 & & \\
\hline & Total & 16.859 & 81 & & & \\
\hline \multirow[t]{3}{*}{ Ease to Learn } & $\begin{array}{l}\text { Between } \\
\text { Groups }\end{array}$ & 4.447 & 3 & 1.482 & 5.574 & .002 \\
\hline & Within Groups & 20.740 & 78 & .266 & & \\
\hline & Total & 25.187 & 81 & & & \\
\hline \multirow[t]{3}{*}{ Satisfaction } & $\begin{array}{l}\text { Between } \\
\text { Groups }\end{array}$ & .723 & 3 & .241 & .998 & .399 \\
\hline & Within Groups & 18.838 & 78 & .242 & & \\
\hline & Total & 19.561 & 81 & & & \\
\hline \multirow[t]{3}{*}{ Total score of USE } & $\begin{array}{l}\text { Between } \\
\text { Groups }\end{array}$ & 1.361 & 3 & .454 & 3.234 & .027 \\
\hline & Within Groups & 10.946 & 78 & .140 & & \\
\hline & Total & 12.308 & 81 & & & \\
\hline
\end{tabular}

IJEME, Vol. 2, No. 1, March 2018, 39-48. 
Based on Table 2 on the last column, it can be known that usefulness and satisfaction factors are not significantly different. It means that all applications have same opportunity (usefulness and satisfaction) to be used in learning. But for the ease to use and ease to learn, there are different response between applications. Socrative app is the best one on both citeria (see also Table 1 for the mean score). The second one is Edmodo. To implement this finding, schools have to create policies to support the utilization of mobile application in learning sustainably. This arrangement will really support the student success in the 21st century learning environment (Gulden et al., 2012; Sulisworo et al., 2017; Tarawneh et al., 2011; Yadegaridehkordi et al., 2015).

\section{CONCLUSION}

Analyzed data from USE questionnaire, student gave high positive response on using social media for their mathematics learning particularly on usefulness and satisfaction factors. Generally, students gave the same response when using different mobile applications. The student comfort in mobile learning occurs because the activities using mobile technology have been experienced in the student daily life. In the policy development to apply mobile learning, it needs to consider the student familiarity in using the application. Furthermore, social media especially that one supported by learning management system has opportunity to be used as learning tool to enhance learning quality for mathematics subject in rural area.

\section{REFERENCES}

Alzahrani, H., \& Laxman, K. (2016). A Critical Review of Meta-analysis Studies on Mobile Learning. Technology, Instruction, Cognition \& Learning, 10(3), 245-258.

Barak, M., Nissim, Y., \& Ben-zvi, D. (2011). Aptness between Teaching Roles and Teaching Strategies in ICT-Integrated Science Lessons. Interdisciplinary Journal of E-Learning and Learning Objects, 7(1), 305-322.

Bozanta, A. (2017). The Effects of Social Media Use on Collaborative Learning : a Case of Turkey. Turkish Online Journal of Distance Education, 18(1), 96-110.

Farisi, M. I. (2016). Developing the 21st-century social studies skills through technology integration. Turkish Online Journal of Distance Education, 17(1), 1630.

Fidaldo, P., \& Thormann, J. (2017). Reaching Students in Online Courses Using Alternative Formats. International Review of Research in Open and Distributed Learning, 18(2), 139-161.

Furberg, A. (2016). Teacher support in computer-supported lab work: bridging the gap between lab experiments and students' conceptual understanding. International Journal of Computer-Supported Collaborative Learning, 11(1), 89113.

Gómez-rey, P., Barbera, E., \& Fernández-navarro, F. (2017). Student Voices on the Roles of Instructors in Asynchronous Learning Environments in the 21 st Century. International Review of Research in Open and Distributed Learning (IRRODL), 18(2), 234-251.

Gulden, T., Sandnes, F. E., \& Habib, L. (2012). Design competence in ICT education. Proceedings of the 14th International Conference on Engineering \& Product Design 
Education (E\&PDE12) Design Education for Future Wellbeing, Antwerp, Belgium, 419-424.

Kabir, F. S., \& Kadage, A. T. (2017). Icts and Educational Development: the Utilization of Mobile Phones in Distance Education in Nigeria. Turkish Online Journal of Distance Education, 18(1), 63-77.

Kashorda, M., Acosta, F. \& Nyandiere, C. (2007). ICT infrastructure, applications, society and education. Proceedings of the Annual Strathmore University ICT Conference 2006, Kenya, 1-101.

Kola, J. (2013). Effective Teaching and Learning in Science Education through Information and Communication Technology [ICT]. IOSR Journal of Research \& Method in Education, 2(5), 43-47.

Kumar, K. L., \& Owston, R. (2016). Evaluating e-learning accessibility by automated and student-centered methods. Educational Technology Research and Development, 64(2), 263-283.

Kumari, A., \& Chamundeswari, D. S. (2013). Self-Concept and Academic Achievement of Students at the Higher Secondary Level. Journal of Sociological Research, 4(2), 105-114.

Ludvigsen, S., Cress, U., Law, N., Rose, C. P., \& Stahl, G. (2016). Collaboration scripts and scaffolding. International Journal of Computer-Supported Collaborative Learning, 11(4), 381-385.

Lund, A. M. (2001). Measuring usability with the use questionnaire12. Usability interface, 8(2), 3-6.

Mahdi, K., Chekour, M., Laafou, M., Janati, R., Idriss, A., \& Madrane, M. (2014). The generalization of using the ICT in the work of the physics teachers in Moroccan schools: Obstacle of training courses and solutions. International Journal of Innovation and Applied Studies, 9(2), 829-834.

Mahdi, K., Laafou, M., \& Janati-idrissi, R. (2015). Qualifications of Physics Teachers in ICT to Integrate the Use of ICT in Moroccan Physics Schools: Obstacles and Solutions. Journal of Educational and Social Research, 5(1), 177-182.

Okpurukhre, W., \& Esiekpe, L. E. (2013). Enhancing the Teaching of Physics Using Information and Communication Technology (ICT) for Optimal Quality Education in Senior Secondary Schools in Delta State. The Global Journal of Educational Perspectives, 1(1), 68-76.

Owate, I. O., Williams, C., \& Nnanna, L. A. (2014). Information and Communication Technology (ICT) Support Systems for Teaching and Learning Physics in Selected Secondary Schools in Eleme Local Government Area. Education, 4(4), 79-87.

Sadaf, A., Newby, T. J., \& Ertmer, P. A. (2016). An investigation of the factors that influence preservice teachers' intentions and integration of Web 2.0 tools. Educational Technology Research and Development, 64(1), 37-64.

Sulisworo, D., Agustin, S. P., \& Sudarmiyati, E. (2016). Cooperative-blended learning using Moodle as an open source learning platform. International Journal of Technology Enhanced Learning, 8(2), 187-198. 
Sulisworo, D., Ishafit, \& Firdausy, K. (2016). The development of mobile learning application using Jigsaw technique. International Journal of Interactive Mobile Technologies, 10(3), 11-16.

Sulisworo, D., Nasir, R., \& Maryani, I. (2017). Identification of teachers' problems in Indonesia on facing global community. International Journal of Research Studies in Education, 6(2), 81-90.

Sulisworo, D., \& Toifur, M. (2016). The role of mobile learning on the learning environment shifting at high school in Indonesia. International Journal of Mobile Learning and Organisation, 10(3), 159-170.

Sulisworo, D., Yunita, L., \& Komalasari, A. (2017). Which Mobile Learning is More Suitable on Physics Learning in Indonesian High School ? International Journal of Recent Contributions from Engineering, Science \& IT (iJES), 5(1), 97-103.

Tarawneh, H., Tarawneh, M., \& Alzboun, F. (2011). Enhancing the Quality of E-learning Systems via Multimedia Learning Tools. IJCSI International Journal of Computer Science Issues, 8(6), 107-111.

Ülen, S., \& Gerlič, I. (2012). The Conceptual Learning of Physics in Slovenian Secondary Schools. Organizacija, 45(3), 140-144.

Uyanga, S. (2005). The usage of ICT for secondary education in Mongolia Sambuu Uyanga. Internasional Journal of Education and Development Using Information and Communication Technology, 1(4), 101-118.

Yadegaridehkordi, E., Iahad, N. A., \& Ahmad, N. (2015). User perceptions of the technology characteristics in a cloud-based collaborative learning environment: a qualitative study. International Journal of Technology Enhanced Learning, 7(1), 75-90.

Zawacki-richter, O., Alturki, U., \& Aldraiweesh, A. (2017). Review and Content Analysis of the International Review of Research in Open and Distance/ Distributed, International Review of Research in Open and Distributed Learning (IRRODL), 18(2), 1-26.

Zyad, H. (2016). Integrating computers in the classroom: Barriers and teachers' attitudes. International Journal of Instruction, 9(1), 65-78. 
